\title{
A methodical approach to the mapping of biotope types by using GIS based remote sensing techniques (Köprülü Kanyon National Park Case / Turkey)
}

\author{
Cumhur Güngöroğlu ${ }^{*}$, , Renate Bürger-Arndt ${ }^{2}$ \\ *, $\left.{ }^{1}\right)$ Department of Soil Science and Ecology, Forest Engineering, Faculty of Forestry, Karabük University, \\ 78050, Karabük, Turkey \\ $\left.{ }^{2}\right)$ Department of Nature Conservation and Landscape Planning, Faculty of Forest Sciences and Forest Ecology \\ Göttingen University, 37077, Göttingen, Germany
}

Corresponding author: cumhurgungoroglu@karabuk.edu.tr

\begin{abstract}
The objectives of nature conservation focused on the protection of selected animal and plant species and individual ecosystems through conservation. The basic components of nature conservation are flora and fauna including their habitats, biodiversity, performance and functionality of the natural environment. These can be directly linked to the goals for ecosystem, species and biotope protection. The main objective of this study is the development of an efficient nation-wide procedure for biotope type mapping. This requires the methodical development of a systematic biotope type mapping. In preparation an exemplary region was chosen the Köprülü Canyon National Park, which covers an area of 35,672.72 ha, The biotope types in the area were recorded, classified and mapped using GIS-supported remote sensed technology. Methods of digital classification were utilized in determining forest types and maquis. The remotely acquired information and the classes had to be combined with other information in order to be processed via GIS. The analysis and evaluation using GIS was the basis for establishing the biotope types. The GIS analysis served to place the polygon and object classes which were classified by visual or digital image evaluation on the biotope type layer. Thus the biotope type layer is a final layer for all biotopeforming shape files that serves the transferring of adjoining polygon classes. The biotopes were classified by coding the homogenous biotope surfaces according to their characteristics. This made it possible to address the biotope types via their properties in various hierarchical levels. The typification and description of biotopes achieved through hierarchic classification. Thereafter, the biotope types were presented as a list together with their descriptions, which contained information used during classification. The characteristics for classification are distinguished by hierarchical level which entails a discreet description of the particularities and characteristics. The biotope types were mapped for each layer in a hierarchical level.
\end{abstract}

Keywords: Biotop types, mapping, GIS, Remote Sensing, Turkey

\section{Introduction}

The basic components of nature conservation are "flora and fauna including their habitats and habitats in the aspect of biodiversity" and "performance and functionality of the natural environment". These can be directly linked to the goals for ecosystem, species and biotope protection. Initially, the tasks and objectives of nature conservation focused on the protection of selected animal and plant species and individual ecosystems through conservation and conservation strategies (Erz 1980, Plachter 1991). The tasks of nature conservation in new approaches were no longer described as merely conventional, conservative and protective, but also as preservative and planned-formative. Such approaches have been 
published in terms of country level (Deixler 1982) and forest biotope mapping (Ammer and Utschik 1982). This required a broader definition of nature conservation. It was from Plachter (1991) formulated as follows: "All measures for the conservation and aid of plants and animals of wild species, their communities and natural livelihoods as well as for protecting landscapes and landscape parts under natural conditions". According to Plachter (1991), with biotope mapping has been provided for the first time a thorough overview of the existence and condition of certain biotope types in Germany. This initial biotope mapping indicated the status and distribution of the most valuable and vulnerable habitats, and as a result, a regionalized evaluation was carried out to derive differentiated protection and development objectives. In recent years, biotope mapping has no longer concentrated solely on natural or semi-natural habitats, but also on the systematic inventory of semi-natural or land-use cultural landscapes serving a purpose-based integrated nature conservation. The mapping of the biotope types allows a nature conservation evaluation of the Wildlife habitats as a planning basis for habitat protection. The protection of biotopes is a central task of nature conservation, which results from the synthesis between the two fields of species and site protection (Erz 1980), Thereafter, the preservation and development of life opportunities for the flora and fauna throughout the landscape (from the natural to the urban and industrial landscape) must be ensured. The term of biotope in this definition is usually not strictly used in the sense of ecology as "habitat of a biocenosis of a certain minimum size and uniformly distinguishable from its environment", but according to Erz (1980) more or less in the sense of the location term as "the totality of the environmental factors acting on the place of residence of an organism". By mapping the biotopes, a sufficiently flexible database can be provided for the needs of the specific conservation plans relevant to nature conservation in order to fulfill legal mandates (Hmuelv 1995). The fields of application of biotope maps are distinguished on the basis of the methodological procedures for mapping the biotopes from a nature conservation point of view. It is important to mention three practical procedures for detecting biotope types:

a) The selective biotope mapping, which includes a targeted collection of protected or legally protected biotopes and forms the basis for (Lanuv 1982, Drachenfels 1993, Ssymank et al. 1993, Hmuelv 1995, Knickrehm and Rommel 1995, Lua 2002):

- the collection of the protected or legally protected biotopes of the countries

- the designation of valuable nature conservation areas

- the preparation of decisions on protected area designations and the Development of protected area systems and their monitoring in the context of the implementation of the Habitats Directive

b) Representative biotope mapping is based on a selective or area-wide biotope mapping and provides a more detailed picture of this through studies on the flora, vegetation or fauna and on site and habitat qualities on selected test areas in a random sampling theory (Hondong, 2002). Representative biotope mapping is used in urban biotope mapping, conservation and development planning for protected areas, landscape and landscape planning, conservation projects and in the context of EIA and Environmental Impact Assessment projects (Hondong 2002, Wächter 2003).

c) In the comprehensive biotope mapping all landscape components of a study area are completely assigned to a specific biotope type (Knickrehm and Rommel 1995), without first determining what is to be regarded as protection required (Lanuv 1982). The comprehensive biotope type maps are a complete survey of all biotope types in a processing area and are mostly used as the basis for the creation of ecological contributions to landscape- and site development plans, the development and implementation of a comprehensive conservation area system of graded intensity (as an inventory system with regard to the conservation and monitoring of biological diversity), the assessment of interventions in the context 
of environmental impact studies and the regional and national red list of endangered biotope types (Drachenfels 1993, Ssymank et al. 1993, Knickrehm and Rommel 1995, Hondong 2002, Lua 2002):

According to Bastian (1997), nationwide biotope mapping provides the value-determining criteria for the assessment of landscape functions with regard to their habitat functions. The comprehensive biotope mapping, which is realized through a uniform survey and assessment of all natural and cultural habitats, has a great importance for the creation and implementation of regional and national species and biotope protection programs (Plachter 1989, Erz 1994), the Red List biotopes (Ssymank et al. 1993, Riecken et al. 1994, Drachenfels 1993), the biotope network (Jedicke 1990) and the integrated protected area system (German Counc1l for Landespflege 1983), landscape and intervention planning (Knickrehm and Rommel 1995, Brinkmann 1997, Ott 1997). An another requirement placed on biotope mapping is the consideration of the hierarchical arrangement of the organizational levels of living beings. This results in a gradation of differently complex habitats, which must correspond to the respective organizational levels of life. When typing biotopes it is therefore important to consider this hierarchy (Haeupler 2002). Finally, biotope type indexes or mapping keys that are created nationwide or used for large-scale planning of the landscape units must be available as a standardized type formation in a hierarchically uniform structure (Ssymank et al. 1993, BfN 1995, Knickrehm and Rommel 1995, Lua Brandenburg 2004), while a distinction or treatment of regionally and locally important biotopes is to be respected.

Although the mapping of the biotopes in Turkey as a planning tool for nature conservation-oriented tasks finds no place, it was carried out as part of scientific research and externally funded projects exemplified. It can be differentiated in urban and rural areas. The first biotope mapping in the urban area was carried out in the city of İzmir (Köseoğlu 1981 and 1983, Y1lmaz 1986). The first biotope maps, which were created in the rural area, are from Uzun et al. (1995) and Altan et al. (2001) in the Çukurova region. There are need new strategies, working methods and instruments based on nature conservation according to Turkey's species-specific and habitat-typical richness. They should primarily enable the planning and management of protected areas based on the biological, geo-ecological and socioeconomic conditions of the country. The main objective of this study is the conception of a nationwide efficient procedure for biotope mapping. The main content of the study consists in the development of a nationwide systematic inventory and exemplary mapping of the biotopes in a protected area.

\section{Material and Methods}

\section{Site Properties}

The study area covers 35,672.72 ha. The area belongs to the counties of Manavgat (about 30,000 ha) with the provincial town of Antalya and Sütcüler (about 5,000 ha) with the provincial town of Isparta. It was declared to the National Park "Köprülü Kanyon" in 1973. The area is located about $90 \mathrm{~km}$ northeast of the city of Antalya in the western part of the Taurian mountain range in southern Anatolia, where the Köprü Çayı (river) forms a basin from north to south into the Mediterranean Sea. The study area is located in the central area of Köprü Irmağı Valley (Fig. 1).

\section{Methods}

\section{Procedures for data collection and analysis}

The determination of biotope properties is an important step in the identification of biotope types. The characteristic values for the identification of the biotope and land use types in the study area were determined by the analogue and digital processing of the data sources (Fig. 2) The analogue data was divided into printed maps, bibliographical references and authorities. The characteristic values for the identification of the biotope and land use types in the study area were determined by the analog and 
Eurasian Journal of Forest Science - A methodical approach to the mapping of biotope by Güngöroğlu and Bürger-Arndt 6(3) 2018

digital processing of the data sources. A procedure has been developed to develop data collection and processing methods for the comprehensive mapping of biotopes (Fig. 3)

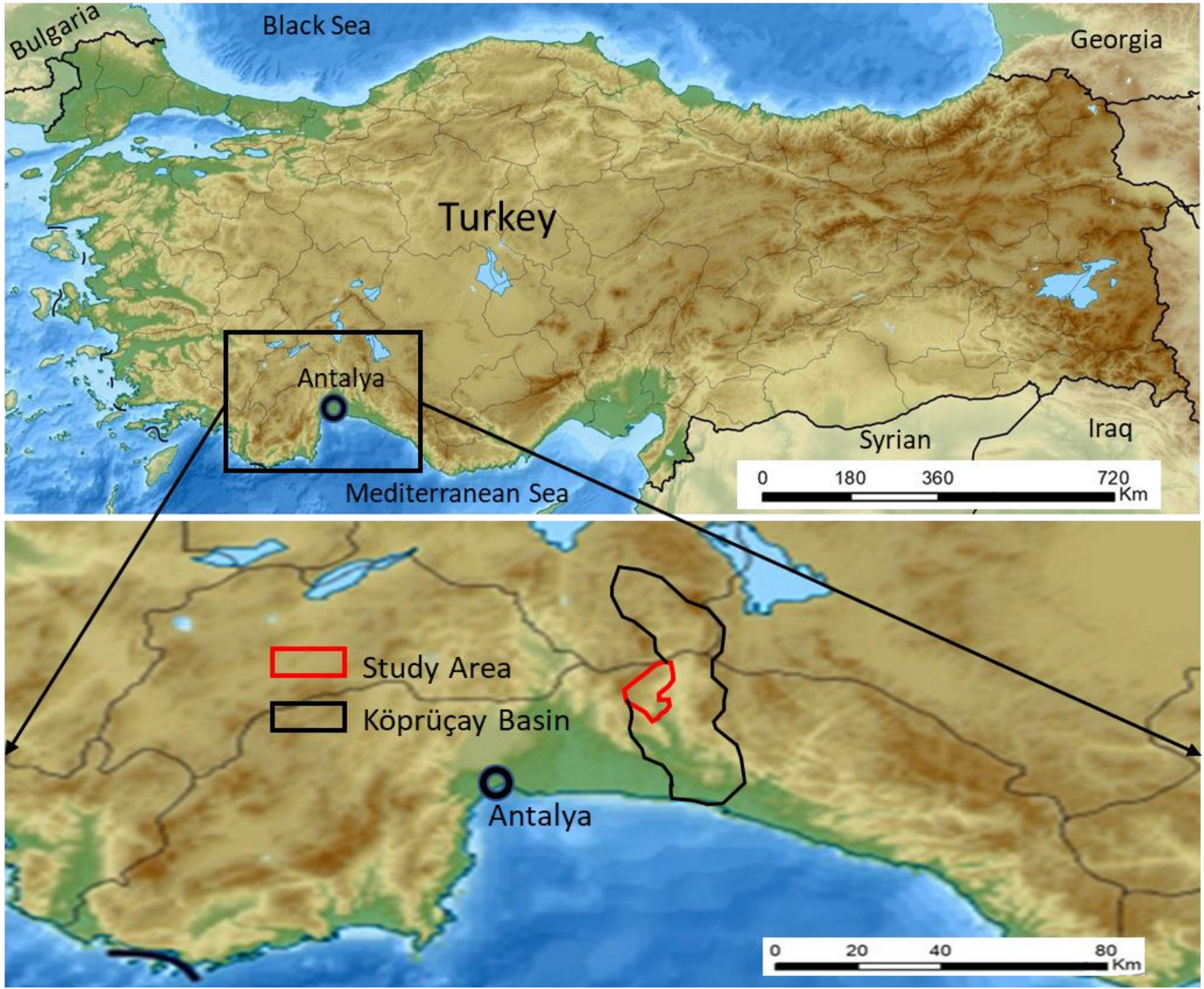

Figure 1. Location of study area

Data sources for determining the characteristic features

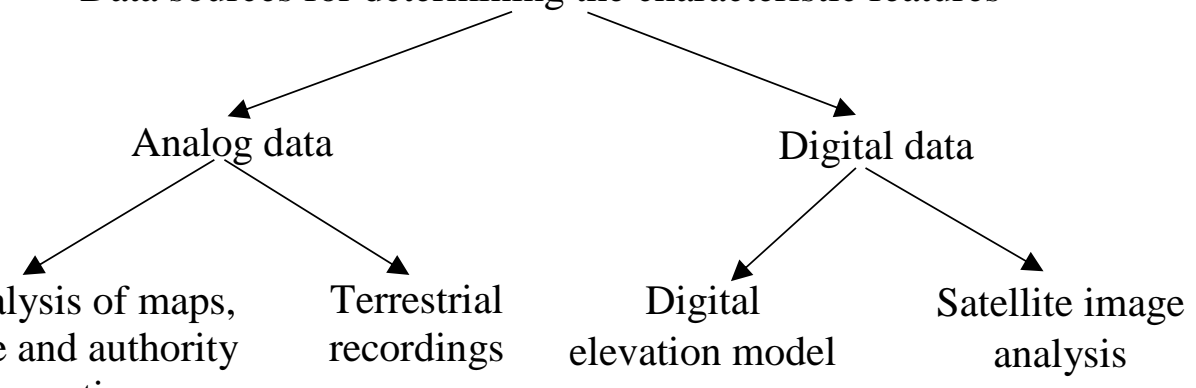
information

Figure 2. Data collection for the characteristics of the biotopes 
Eurasian Journal of Forest Science - A methodical approach to the mapping of biotope by Güngöroğlu and Bürger-Arndt 6(3) 2018

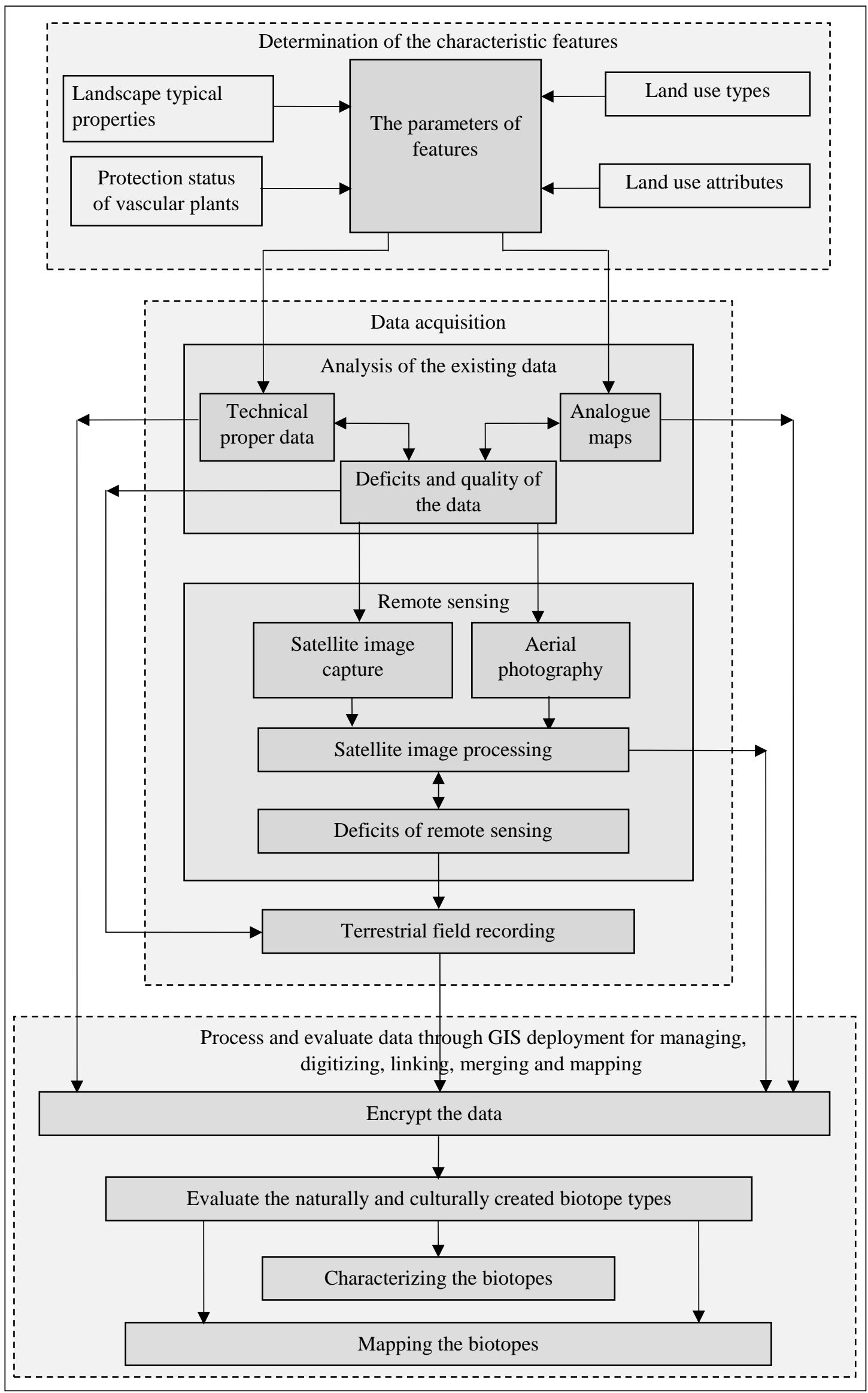

Figure 3. Procedure for recording biotope types 


\section{Assessment of the vegetation and land use properties}

The vegetation characteristics for ecology and vegetation distribution, phytosociological and physiognomic characteristics and human influence provided the data for the characterization of biotope characteristics with regard to vegetation expression and land use. In addition, the vegetation types described in vegetation tables and their species were used to identify the biotopes (as a sample class of vegetation). Ayaşligil (1987) 's vegetation survey was used to obtain this information. The data on stratification, species-specificity and sociability of individual species were compared with location of characteristics such as slope, exposure and altitude as well as the bedrock and degree of vegetation in order to determine the spatial differentiation of characteristic plant species in the biotopes. The studies published by Kantarc1 (1982 and 1990) on the relationship between the distribution of natural tree and shrub species and the regional site characteristics of the Turkish Mediterranean provided important information for the site identification of the biotopes. From the forest inventory maps, the data on the tree species composition, the degree of cover, the layering and stock development phase as well as the distribution of the tree species for the characterization of the forest biotopes are obtained. From these data, especially the tree species composition, the degree of cover and the distribution of the tree species were used as additional data in the evaluation of the satellite imagery. The rock types were digitized from the geological map (MTA 1995) to be used as a layer for classification. The significance of determining the types of land use for this study lies in distinguishing the natural given from the manmade structures of the landscape (Walz et al. 2001) and spatially delineating and typifying the land uses that occur. Only then can the naturally and culturally created structure of the landscape be comprehensively recorded on the basis of the biotope type mapping and the human influence with its consequences on the landscape elements and the structuring of the landscapes recognized. For the impact of human impact on the landscape, land use attributes are used to identify land use types.

\section{Encryption of the homogeneous feature classes}

The coding of the biotope types follows the hierarchical classification system and translates this into a numerical code. This gives the properties relevant to the biotope type at the various hierarchy levels. The goal of encryption of the biotope types is to record the hierarchical assignment category of landscape units at the various levels. The biotopes are encoded by the plane-by-plane homogeneity of their specific properties, which is a characteristic that is clearly different from others. Each level has a special significance for the labeling of biotope types. It was planned to limit the level number, because otherwise the classification into the sublevels will make it too confusing. Encryption has only formed three levels so far, but the encryption concept provides four or five levels to allow further differentiation where needed (Fig. 4).

\section{Data preparation and processing using remote sensing techniques}

To collect and analyse of data was used remote sensing and GIS techniques. Remote sensing played an important role in the storing of extensive area information. The results of the satellite image analysis were used to address vegetation types. The topographical map sheets on a scale of 1:25000 standard topographic maps of Turkey, produced by the General Directorate of Mapping for Turkey and with the geodetic reference system (UTM 1950 ED) are georeferenced according to the geodetic projection of the IKONOS 2 (geometrically corrected one frame, Pan+MSI 4 channel image type, acquisition Date/Time: 2003-06-13 08:59 GMT, pixel resolution $1 \mathrm{~m}$ ) satellite imagery (UTM WGS 1984). Subsequently, they were used as a basis for the map applications of vegetation, geology and forest stands as well as for the geocoding of the GCP (Ground Control Points) for referencing the objects from IKONOS satellite images. In addition to satellite imagery, the 1/15000 CIR aerial imagery available was 


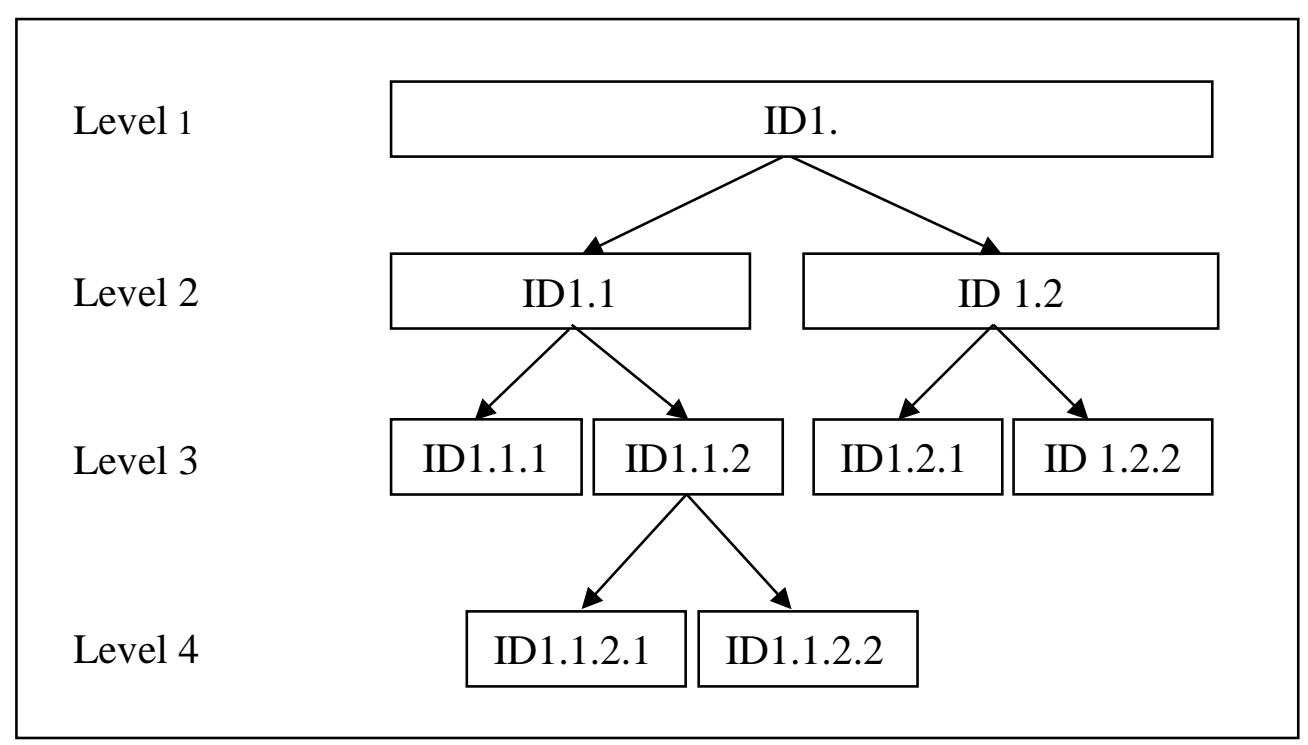

Figure 4. Encryption of biotope types in a hierarchical classification system

used for visual interpretation to identify forest tree species. The digital data was derived from the digital elevation map and the satellite image interpretation. The data basis for creating a digital elevation model were the files in e00. ARC/INFO coverage formats on a scale of 1/25000. Parameters such as slope, exposure, altitude classification and large-scale relief shapes were generated from the digital elevation model. The areas for the vegetation units and land use types were obtained by applying the digital image analysis methods. The terrestrial methods were mainly used to eliminate uncertainties or to increase the quality of remote sensing data. The content and methods of terrestrial recording are determined by the quality of the IKONOS images.

\section{Using GIS in the hierarchical classification of the biotope types}

The feature classes obtained by evaluating the image data were used in GIS together with other data for the characterization and classification of the biotope types. The role of GIS was very important in classifying the biotopes, using various software tools for operations or implementations such as converting, exporting, importing, storing, editing, querying, intersecting, georeferencing, selecting, extracting and mapping the data. A digital elevation model was created in grid cells. This was important for the site-morphology-related local features and further in the coding and typing of the biotope types. The advanced GIS analyses used to transfer of homogeneously characterized feature classes, encryption of homogeneous feature classes, hierarchical classification of encrypted biotope types. The determination of the biotope properties by using GIS serves both to distinguish homogeneous units which are characterized by certain features or feature groups, and to develop a classification system which follows a hierarchical arrangement of the homogeneous units at different levels. These features must be coded according to the GIS data foundation. The classification of the biotopes follows a hierarchical demarcation and classification of homogeneous spatial units with regard to different characteristic values of the respective biotope type (Fig. 5). 


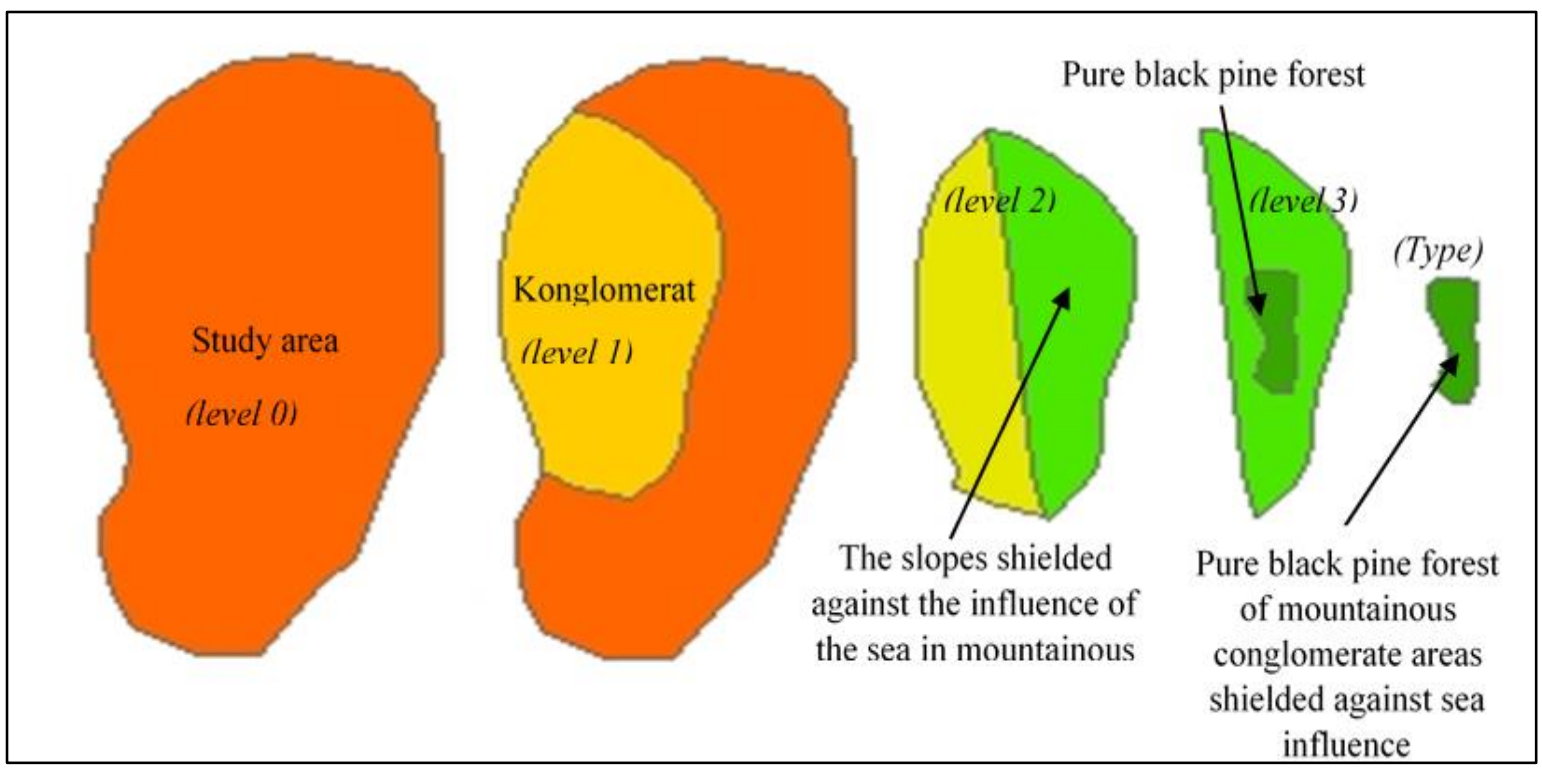

Figure 5. Exemplary representation for the GIS classification and typing of the biotopes in the study area

\section{Data collection and analysis using remote sensing and GIS techniques}

The topographical map sheets on a scale of 1 / 25000 and with the geodetic reference system (UTM $1950 \mathrm{ED})$ are geo-referenced according to the geodetic projection of the IKONOS satellite images into the geodetic projection UTM WGS 1984. Subsequently, they were used as a basis for the map applications of vegetation, geology and forest stands as well as for the geocoding of the GCP (Ground Control Points) for the referencing of objects from IKONOS satellite imagery. In addition to these satellite imagery, the 1/15000 CIR aerial imagery available was used for the visual interpretation of some objects taken for the identification of forest tree species. The digital data was derived from the digital elevation maps and the satellite image processing. Parameters such as slope, exposure, altitude and large-scale relief forms were generated from the digital elevation model. The areas for the vegetation units and land use types were obtained by applying the digital image analysis methods.

\section{Results}

The following biotope properties were determined by data collection and analysis method including satellite imagery analysis and GIS techniques (Table 1).

Vegetation units and their bioclimatic characteristics in relation to the altitude levels determined for the study area which was important to characterise the special features for individual vegetation types (Table 2).

Remote sensing techniques have been used intensively in the separation of forest types. One of the techniques applied for this is to distinguish the spectral reflectance values of tree species (Fig. 6). Supervised and unsupervised classification techniques are frequently used in forest areas where forest types cannot be visually classified (Fig. 7). ISODATA-Clusteranalyse was used for uncontrolled classification. Depending on the density of the vegetation, the areas were cut from the image. 15 classes and 20 iteration are used for each cutted image. A supervised classification was performed for all objects that could not be assigned to any class by ISODATA cluster analysis. Such classes have been classified used to the maximum likelihood classifier by spectral signature analysis. The visual interpretation was performed by the scale changes and band changes. Accuracy assesment procedures were applied to test the accuracy of these classifications (Fig. 8). 
Table 1. List of determined biotope properties

\begin{tabular}{|c|c|}
\hline Characterized features & Classes \\
\hline Land uses & $\begin{array}{l}\text { afforestation, utilization of wood, grazing, forest fire, recreation, tourism, } \\
\text { dry crop cultivation, irrigated field crops, fallow fields, traffic circulations, } \\
\text { residential areas, others }\end{array}$ \\
\hline $\begin{array}{l}\text { Frequency of encroachments by } \\
\text { land usages }\end{array}$ & regularly, irregularly, not any \\
\hline Daily usage time & permanently, only by day, only in the evening/at night \\
\hline Yearly usage time & permanently, seasonally \\
\hline Accessibility & good, moderate, low, none \\
\hline $\begin{array}{l}\text { Special features for individual } \\
\text { vegetation types }\end{array}$ & $\begin{array}{l}\text { Forest (pure coniferous or deciduous, mixed coniferous or deciduous, mixed } \\
\text { deciduous and coniferous forest, mixed coniferous and sclerophyllus shrubs, } \\
\text { mixed deciduous and sclerophyllus shrubs, mixed deciduous and coniferous } \\
\text { forest with sclerophyllus shrubs) } \\
\text { Woody plants (shrubs and dwarf shrubs) } \\
\text { Montane to subalpine xeromorphic open dwarf shrublands and grasslands in } \\
\text { the mountains (montan and subalpin, moist or dry) Riparian vegetation } \\
\text { (river, stream, siltation areas) } \\
\text { Cleft vegetation (mediterranean, montane, high montane-subalpine), Areas } \\
\text { degraded by rural uses (abandoned farmland, burnt areas, lands degraded by } \\
\text { deforestation, by overgrazing degraded areas, strong to very strongly or little } \\
\text { to moderately eutrophicated areas, intervened very strongly, strongly, } \\
\text { moderately and little) } \\
\text { Agricultural land (cereals, vegetable growing, fruit production, mixed } \\
\text { cultivation, non-wood products, beekeeping, carob, thyme, sweet chestnut) } \\
\text { Settlements and streets (village, hamlet, massive use, single or group use, } \\
\text { continuous use, discontinued use, official use, two or one lanes and traffic- } \\
\text { tight or low) }\end{array}$ \\
\hline Characteristic plant species & $\begin{array}{l}\text { Coding of the characteristic plant groups, for example: } \\
182 \text { Pinus brutia and Glycyrrhiza asymmetrica formation }\end{array}$ \\
\hline Canopy closure degree & closed $\% 70-100$, half closed $\% 40-70$, light closed $\% 10-40$, open $\% 0-10$ \\
\hline
\end{tabular}
shrub layer

Layering of the vegetation
Other features of the vegetation

two or more, one, not layered

Other features of the vegetation rich in lying and standing deadwood, rich in young growth, rich in herbs, rich in chasmophytes, geophytes, thermophytes, rich in anthropogenic plant species, rich in fire sensitive species, rich in shrub and herbaceous species, rich in tree and wood species.

Climate zone of plant society Oleo-Ceratonion Zone: hot and rainy winters

Quercion calliprini zone: mild and rainy winter

Querco-Cedretalia libani zone: cold to very cold and moderately rainy winter

Astragalus Brometea Zone: cool to frosty, winter with little rainfall

\begin{tabular}{|c|c|}
\hline Stand development phase & Older, young, mixed \\
\hline Structure of the surface & $\begin{array}{l}\text { uncovered soils, soils and loose gravel and debris, mostly stones and gravel, } \\
\text { partly soils, mostly loosened blocks, partly with gravel and soil, rough } \\
\text { stones, Boulders and rock wall, rockfill }\end{array}$ \\
\hline Rock formation & $\begin{array}{l}\text { Holocene deposits in valleys and polders, sedimentary areas, Beşkonak } \\
\text { Formation, Köprüçay Conglomerate, Mesozoic-Old Tertiary Formations, } \\
\text { Radiolarites and Upper Triassic Sandstones }\end{array}$ \\
\hline $\begin{array}{l}\text { Geologically and } \\
\text { geomorphologically important } \\
\text { areas }\end{array}$ & $\begin{array}{l}\text { Valleys (canyon- and deep-shaped, inliers), karst forms (poljen, sinkholes, } \\
\text { barrow), half karst formations, cirques, snow erosion pans, firn patch) }\end{array}$ \\
\hline Slope classes & $\begin{array}{l}\text { plane, slightly inclined, moderately inclined, inclined, strongly inclined, } \\
\text { steep, very steep }\end{array}$ \\
\hline Slope exposure & plane, north, east, south and west exposed \\
\hline Waters & $\begin{array}{l}\text { perennial, periodic, standing, spring, gravel and sand banks in the flooded } \\
\text { bank area }\end{array}$ \\
\hline
\end{tabular}


Table 2. Vegetation units of the study area and their bioclimatic characteristics in relation to the altitude levels

\begin{tabular}{|c|c|c|c|}
\hline & Vegetation units & Altitude (m.) & Bioclimatic characteristics \\
\hline \multicolumn{2}{|r|}{ Astragalo-Brometea } & $2500 \mathrm{~m}$ & $\begin{array}{l}\text { Mediterranean-subalpine / high-montane } \\
\text { vegetation stage, with cool to frost-rich and } \\
\text { rain-poor winter }\end{array}$ \\
\hline \multicolumn{2}{|r|}{ Querco-Cedretalia libani } & & $\begin{array}{l}\text { Mediterranean-montane vegetation, with } \\
\text { cold to very cold and rainy winter }\end{array}$ \\
\hline \multirow{3}{*}{ 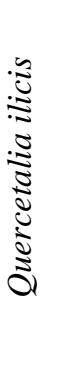 } & Quercion calliprini & $500 / 600 \mathrm{~m}$ & $\begin{array}{l}\text { Upper Mediterranean vegetation with } \\
\text { temperate and rainy winter }\end{array}$ \\
\hline & $\begin{array}{l}\text { Quercion calliprini } \\
\text { Oleo-Ceratonion }\end{array}$ & & $\begin{array}{l}\text { Meso-Mediterranean vegetation with } \\
\text { warm / mild and rainy winter }\end{array}$ \\
\hline & Oleo-Ceratonion & $100 / 110 \mathrm{~m}$ & $\begin{array}{l}\text { Thermo-mediterrane Vegetationsstufe } \\
\text { mit warmem und regenreichem Winter }\end{array}$ \\
\hline
\end{tabular}

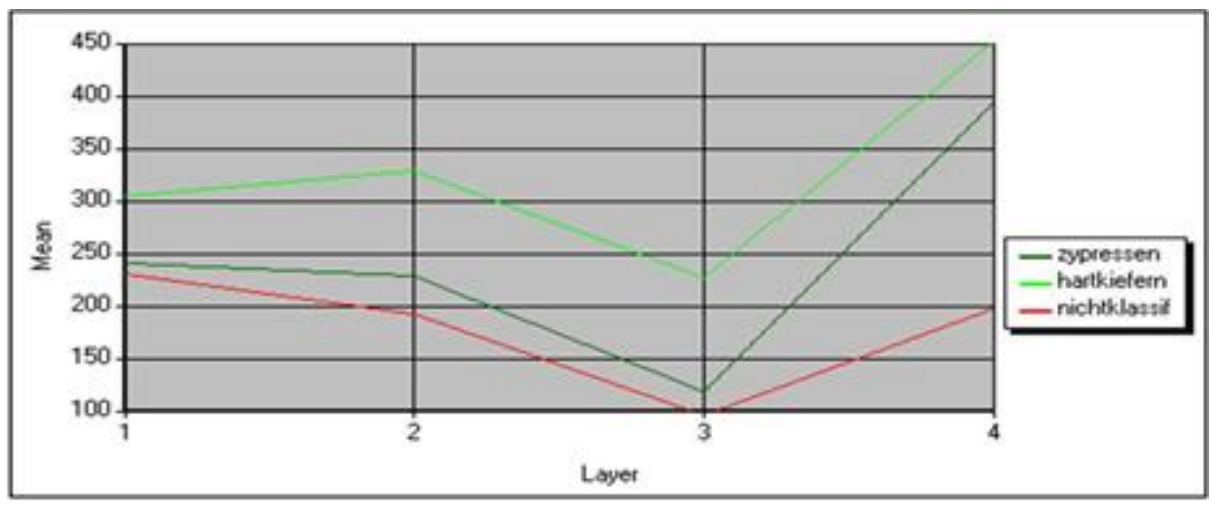

Figure 6. The distribution of spectral signatures of IKONOS images according to tree species (cypress: dark green, Turkish red pine: light green and unclassified: red)

For the coding of the biotope types, a hierarchical subdivision and classification of the biotope types initially classified in the first level was carried out. This required different GIS operations that required a different approach for each characteristic in terms of its raster or vector format. The class-related database attributes had to be prepared before, or after, entered, or transmitted according to the type of operation ( $\rightarrow$ overlay intersect). The following figures were used to illustrate the hierarchical classification under the level 1 (forests). Here, the layers of characteristics were selectively retrieved after the first-level biotope classes in a new layer and then categorized according to their unique feature classes. By intersecting two vector layers, the result classes were extracted to other new layers. Here in (Fig. 9), the rock types and forests (level 1) are combined in one layer to determine which rock types are important for the area-wide forest distribution. Then the rock types were selected and extracted with the forest types (special features for vegetation) by the clip operation. This marked the forest types that only exist on conglomerate, which is the first step in the classification for level 2. 
Then the forest types (special features for vegetation) were selected on this layer. The different types of forest within conglomerate mountain forests have been specified. Therefore, a classification template for forest types still had to be designed. The forest types were selected by the main tree type via characteristic plant species and blended by overlay intersect with the previous layer. Then the pure mountain black pine forests occurring on conglomerate and dry and cold slopes were classified (Fig. $10)$.

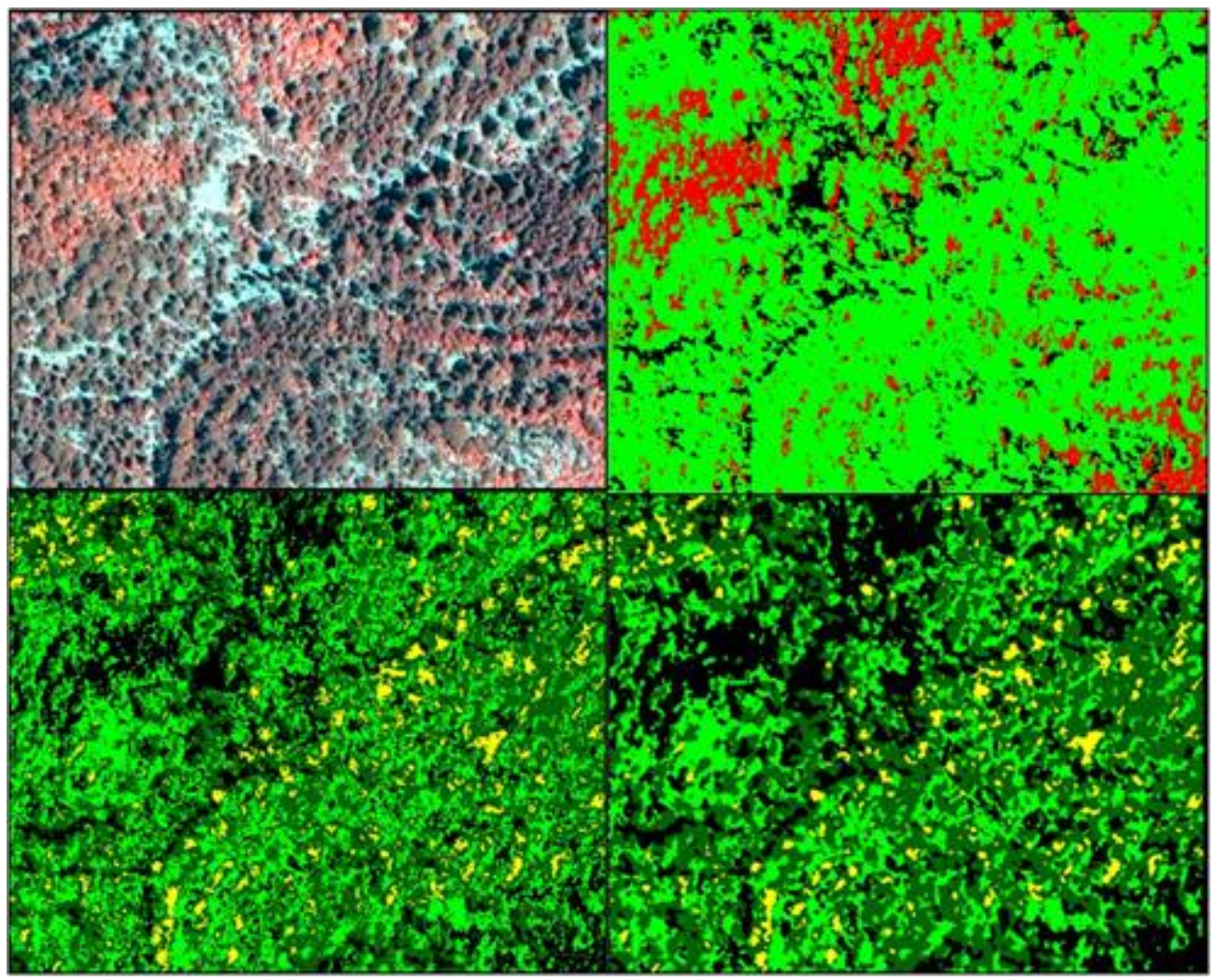

Figure 7. Top left, IKONOS image data in RGB true color representation; top right, the classes of ISODATA cluster analysis; bottom left, results of the Maksimum-Likelihood classification; bottom right, classes related to neighborhood relationships in block structures

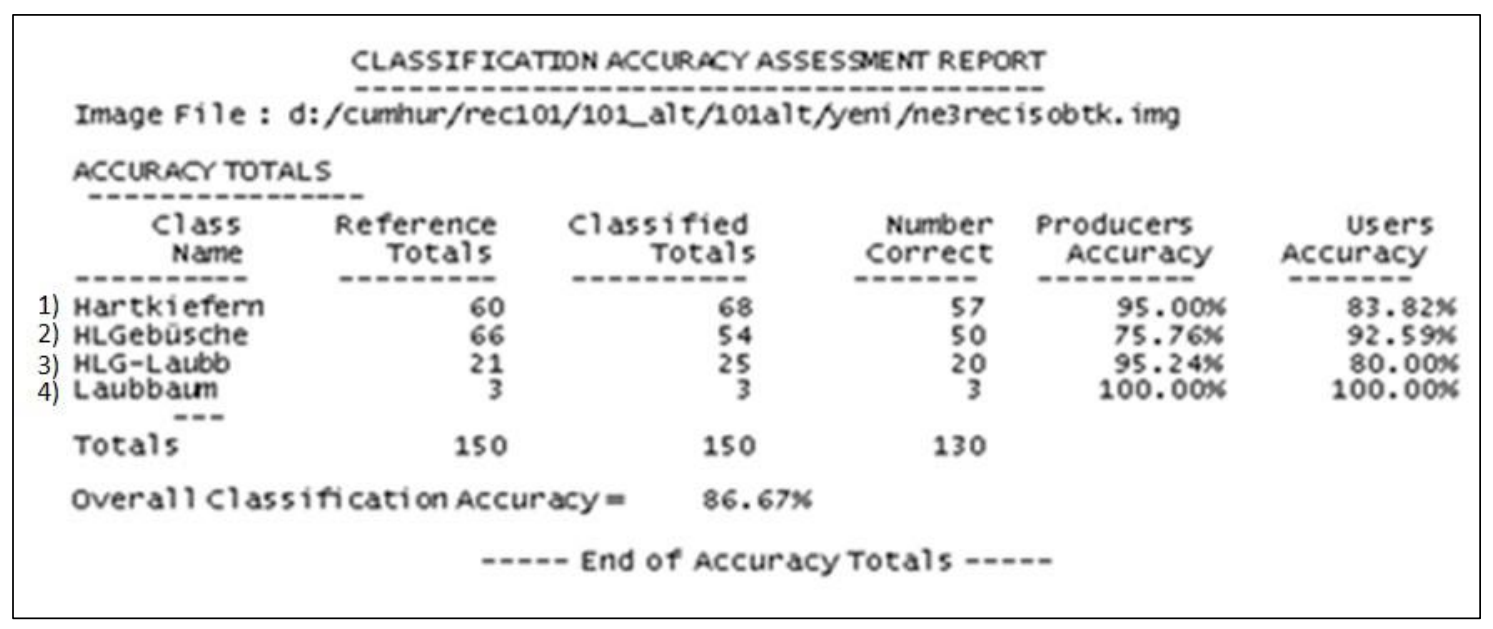

Figure 8. The accuracy assessment report for an unsupervised classification (1: Turkish red pine, 2: sclerophyllous bushes, 3: sclerophyllous bushes and deciduous forest, 4: deciduous forest) 

Bürger-Arndt 6(3) 2018

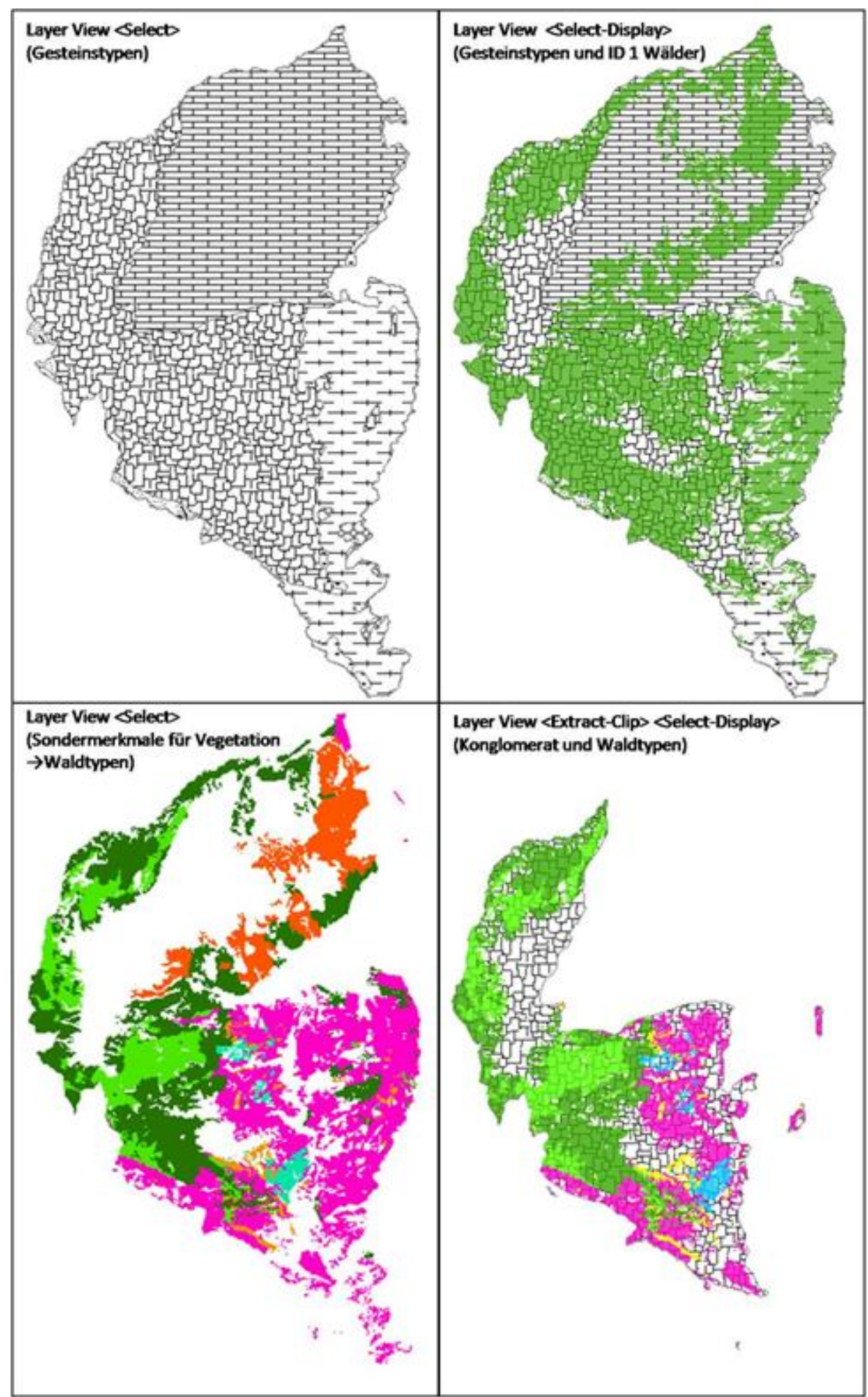

Figure 9. The steps for extracting the forest types of special features for vegetation with rock types 


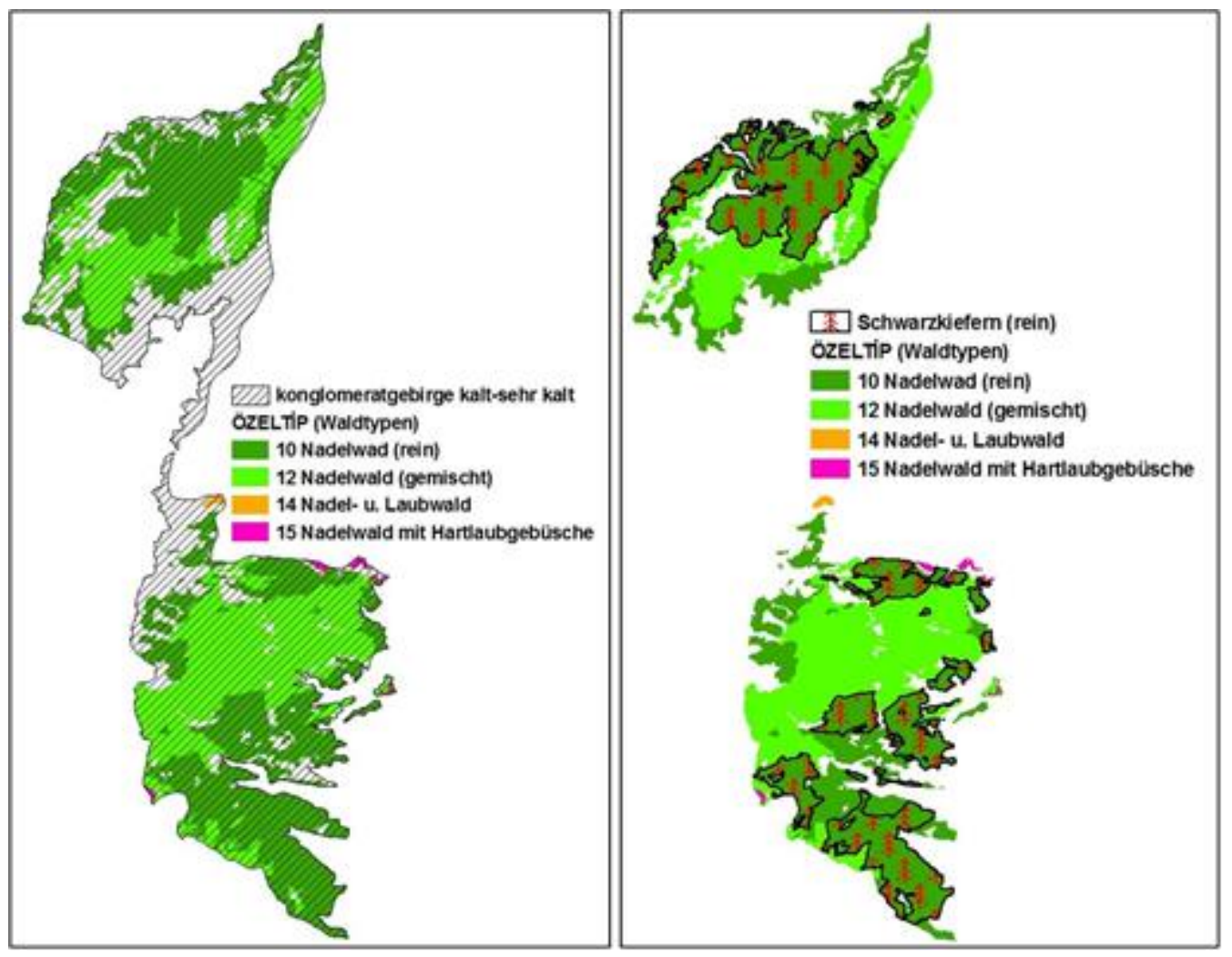

Figure 10. The intersection for the extraction of the conglomerate dry cold mountain forests, on slopes shielded against the influence of the sea (Level 2) and those of the black pine mountain forests (Level 3)

As a result of this study, maps were produced for each level. Eight biotope types were identified at the first level. The number of 3rd level biotop types in level 1 is also shown in (Fig. 11). The total area of the 1st level biotope types are given in (Fig. 12). Thirty-seven biotope types were identified at level 2. A total of 102 different biotope types in level 3 were distinguished in different surface areas. This map shows the all biotope types in the hierarchy at least. The forests were in the first place in terms of number of biotop types and total area size. The mapped all bitope types in level 3 shown in (Fig. 13).

\section{Discussion}

The biotope types were classified by coding the homogeneous biotope area based on their characteristic features. There are difficulties on compilation of data on vegetation, topographical land forms and land use becomes very complex. The available data and their informative value must be closely examined with regard to their quality for the determination of biotope properties. The biotope types are classified as the biotope type approach according to hierarchically arranged properties. All characteristic biotope features in the various hierarchical levels were determined in advance. This allows a clear classification and characterization of the biotope types at certain levels by coding the characteristics. The diversity of the characteristic values could be represented by numerous subdivisions of a biotope area into hierarchically classified types, which would otherwise have remained unstructured and unclear. Remote Sensing and GIS techniques are the most important tools for data capturing, analyzing and assessing biotopes. Due to their comprehensive coverage and rapid accessibility of the landscape elements and structures, and their linkability with other data layers by means of GIS are more favorable than field recordings, especially for area-wide biotope mapping. On the other hand it is possible, with the remote 


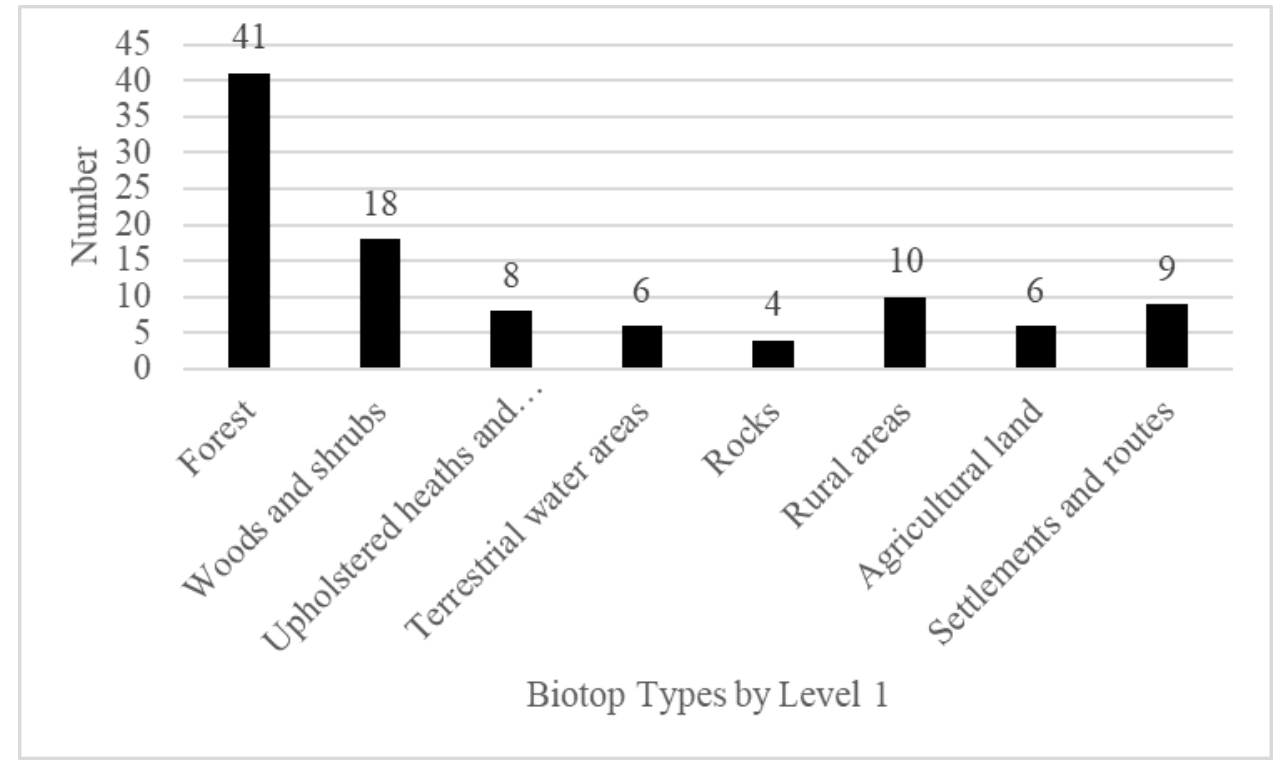

Figure 11. Number of biotope types by Level 1

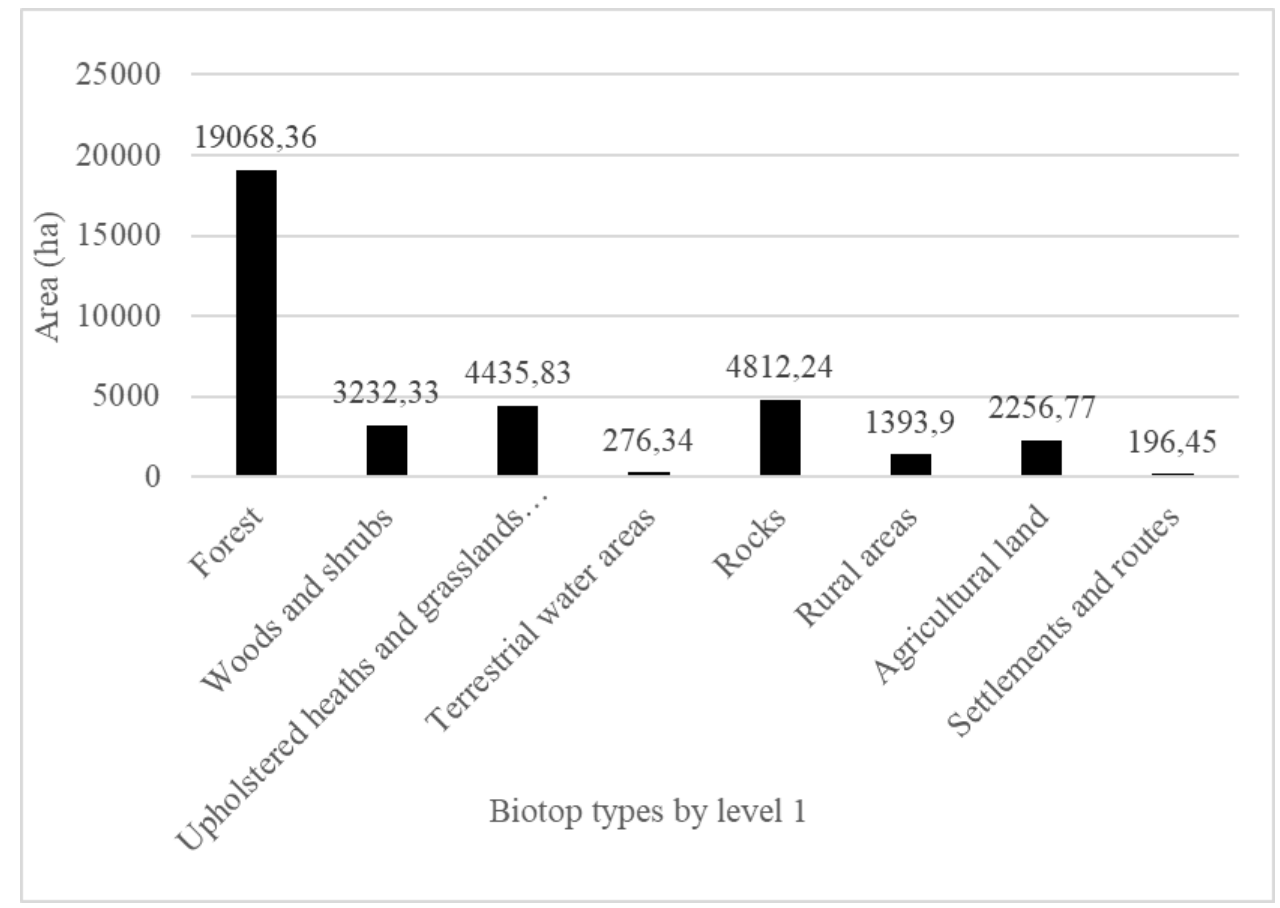

Figure 12. Areal distribution of biotope types by Level 1 
Eurasian Journal of Forest Science - A methodical approach to the mapping of biotope by Güngöroğlu and Bürger-Arndt 6(3) 2018

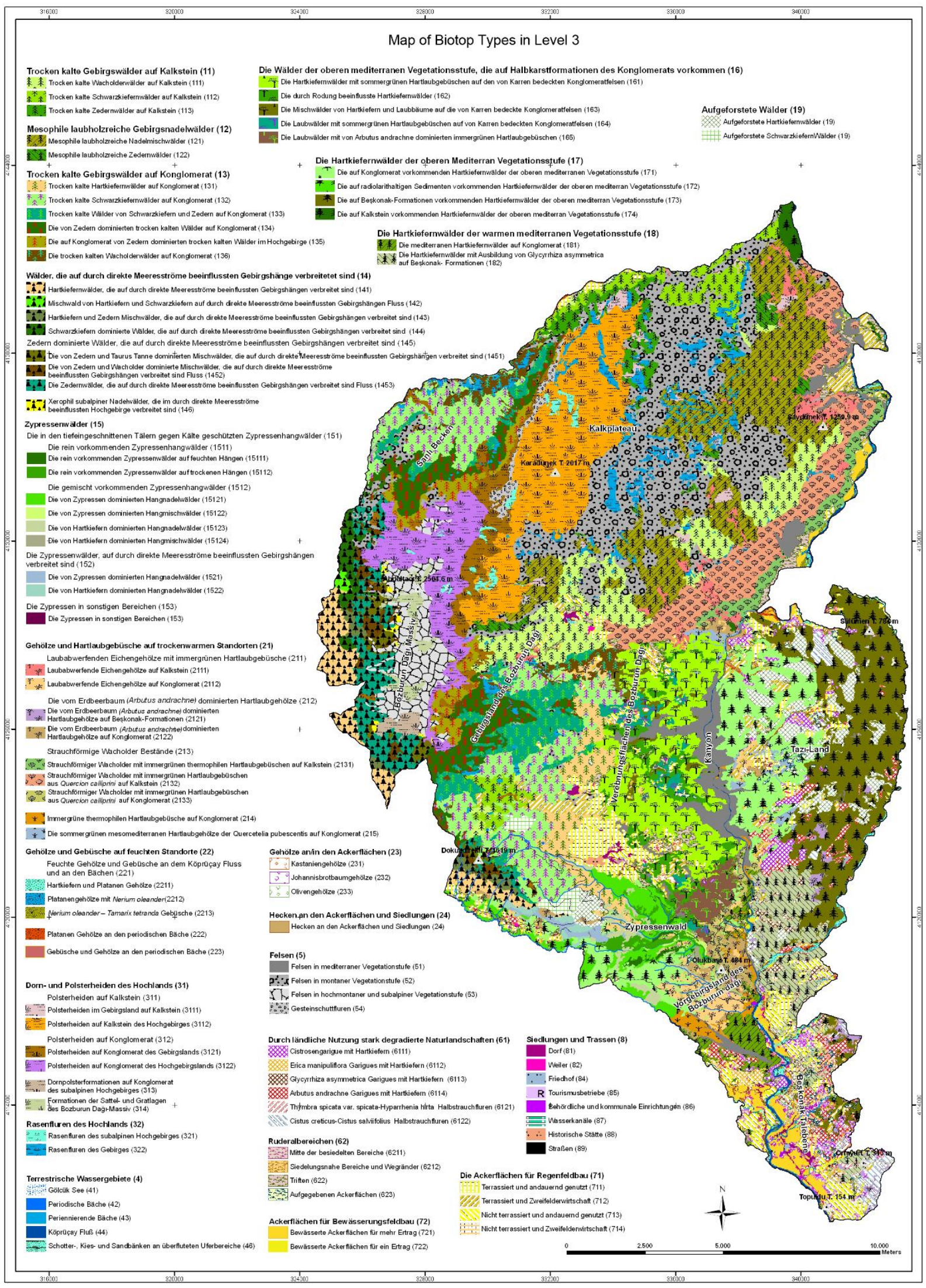

Figure 13. The bitope types of study area 
data, to compile a complete collection or supplementation of the data that is essential for the biotope mapping, but in the existing data situation previously missing. The central importance of GIS analysis and assessment for this study lies in the spatial synthesis of properties and features to biotope types. In this study was given the important corner points of biotope mapping for Turkey. Turkey serves its membership negotiations with the EU since 2005. Those negotiations with Turkey are presented each year to the EU progress report. The requirements of biotope mapping in Turkey is reported since 2008. This study is expected to provide a significant contribution to biotope mapping work holds an important place for the protection of Turkey's nature. Mapping of biotope types is particularly important in the protected areas of Turkey.

\section{Acknowledgements}

This study produced from a dissertation from Göttingen University, entitled, Entwicklung eines Biotopkartierungsverfahrens für die Türkei mit Hilfe von GIS- und Fernerkundungstechnik (Fallbeispiel Nationalpark Köprülü Kanyon) and its supported by DAAD (German Academic Exchange Service) by granting a three-year graduate scholarship.

\section{References}

Altan, T., Tischew, S., Artar, M. (2001). Çukurova deltası biyosfer koruma alanı için biyotop tiplerinin saptanması ve haritalanması. IV. Ulusal Çevre Mühendisliği Kongresi, Mersin.

Ammer, U. and Utschik, H. (1982). Methodische Überlegungen für eine Biotopkartierung im Wald. Forstwissentschaftliche Centralblätter, 101, 60-68.

Ayaşlıgil, Y. (1987). Der Köprülü Kanyon Nationalpark - Seine Vegetation und ihre Beeinflussung durch den Menschen. Landschaftsökologie Weihenstephan; Heft 5. Freising, 307 S.

Bastian, O. (1997). Gedanken zur Bewertung von Landschaftsfunktionen - unter besonderer Berücksichtigung der Habitatfunktion. NNA-Berichte, 10. Jg., 3, 106-125.

BfN (1995). Systematik der Biotoptypen- und Nutzungstypenkartierung (Kartieranleitung). Standard-Biotoptypen und Nutzungstypen für die CIR-Luftbild-gestützte Biotoptypen- und Nutzungstypenkartierung für die Bundesrepublik Deutschland. Schriftenreihe für Landschaftspflege und Naturschutz, Heft 45.

Birkner, H. J. (1995). Fernerkundung, digitale Bildverarbeitung und GIS. In: Buziek, G. (Ed.), GIS in Forschung und Parxis. Verlag Konrad Wittwer, Stuttgart, pp. 93-109

Deixler, R. (1982). Biotopkartierung in Bayern. Forstwissentschaftliche Centralblätter, 101, 54-60.

DEUTSCHER RAT für LANDESPFLEGE (1983): Ein Integriertes Schutzgebietssystem zur Sicherung von Natur und Landschaft - entwickelt am Beispiel des Landes Niedersachsen -. Der Schriftenreihe des Deutschen Rates für Landespflege, 41, 5-15.

Drachenfels, O. v. (1993). Möglichkeiten und Probleme der Auswertung von Biotopkartierungen für eine Rote Liste gefährdeter Biototypen. Schriften Reihe für Landschaftspflege und Naturschutz, 38, 33-46.

Erz, W. (1980). Naturschutz - Grundlagen, Probleme und Praxis In Buchwald, K.- Engelhardt, W. (ed.) "Handbuch für Planung, Gestaltung und Schutz der Umwelt" BLV Verlagsgesellschaft, München, pp. 560-637.

Haeupler H. 2002. Die Biotope Deutschlands. Schriftenreihe für Vegetationskunde, 38, 47-272.

Hmuelv (1995). Hessische Biotopkartierung. Kartieranleitung. Hessisches Ministerium für Landesentwicklung, Wohnen, Landwirtschaft, Forsten und Naturschutz. http://interweb1.hmulv.hessen.de/imperia/md/content/internet/pdfs/naturschutzundforsten/kartiean.pdf (Visited on date: 04.05.2009)

Hondong, H. (2002). Inventuren als Informationsinstrumente der Naturschutzplanung. Methodische Ansätze zur Erfassung von Landschaftsqualitäten für den Arten- und Biotopschutz in der Bundesrepublik Deutschland - mit 
einer Fallstudie am Beispiel von drei Gemarkungen der Schwarzwald-Tieflagen-. Doctoral Thesis. Georg-AugustUniversität Göttingen, Mathematisch-naturwissen-schaftliche Fakultäten.

Jedicke, E. (1990). Biotopverbund. Grundlagen und Maßnahmen einer neuen Naturschutzstrategie. Ulmer Verlag, Stuttgart. 287 S.

Kantarc1, M.D. (1982). Akdeniz Bölgesi'nde Doğal Ağaç ve Çalı Türlerinin Yayılıșı İle İlgili Bölgesel Yetișme Ortamı Özellikleri Arasındaki İlişkiler, İ.Ü. Yayın No: 3054, Orman Fakültesi Yayın No: 330, (VIII+104), Matbaa Teknisyenleri Basımevi, İstanbul.

Kantarcı, M. D. (1990). Akdeniz Bölgesi'nin Yetişme Ortamı Bölgesel Sınıflandırması. OGM Basımevi, Ankara, pp. 150.

Knickrehm, B., Rommel, S. (1995). Biotoptypenkartierung in der Landschaftsplanung. Natur und Landschaft, 70. Jg., 11, 519-528.

Köseoğlu, M. (1981). Peyzaj Ekolojisi Çalışmalarıve Ege Bölgesinde Ekolojik Yönden Önemli Biyotopların Haritalanması Üzerine Bir Araştırma. Ege Ü. Ofset Atölyesi, İzmir.

Köseoğlu, M. (1983). Bornova Yerleşim Merkezinde Ekolojik Yönden Önemli Biyotoplar Üzerine Araştırmalar. Ege Ü. Ziraat Fakültesi Yayınları.

Lanuv (1982). Biotopkartierung Nordrhein-Westfalen. Landesanstalt für Natur, Umwelt und Verbraucherschutz Nordrehein-Westfalen. Recklinghausen.

Lua (2002). Katalog der natürlichen Lebensräume und Arten der Anhänge I und II der FFH-Richtlinie in Brandenburg, Naturschutz und Landschaftspflege In Brandenburg $11(1,2)$.

Lua Brandenburg (2004). Biotopkartierung Brandenburg. Band 1 Kartierungsanleitung und Anlagen. Landesumweltamt Brandenburg, Potsdam, pp. 312.

MTA (1995). Isparta K 10 Paftası Jeoloji Haritası. Maten Tetkik ve Arama Genel Müdürlüğü, Ankara.

Ott, S. (1997). Methodik der Eingriffsregelung - Vorschläge zur bundeseinheitlichen Anwendung der Eingriffsregelung nach $\S 8$ Bundesnaturschutzgesetz. NNA-Berichte, 10. Jg., 3, 2-8.

Plachter, H. (1991): Naturschutz. UTB Gustav Fischer Verlag, Stuttgart, Jena, pp. 463.

Ssymank A., Riecken U., Ries, U. (1993): Das Problem des Bezugsystems für eine Rote Liste Biotope. Schr.-R. f. Landschaftspflege und Naturschutz, 38, 47-58.

Uzun, G., Yücel, M., Yılmaz, T., Berberoğlu, S. (1995): Çukurova Deltası Örneğinde Kıyı Ekosistemlerinin İçerdiği Biyotopların Haritalanması. TÜBİTAK ProjeNo TBAG-1164.

Wächter, M. (2003). Die Stadt: umweltbelastendes System oder wertvoller Lebensraum? - Zur Geschichte, Theorie und Praxis stadtökologischer Forschung in Deutschland. UFZ - Doktoral Thesis. Technische Universität Berlin.

Walz, U., Syrbe, R. U., Donner, R., Lausch, A. (2001). Erfassung und ökologische Bedeutung der Landschaftsstruktur. Workshop der IALE-Arbeitsgruppe Landschaftsstruktur. Naturschutz und Landschaftsplanung $33(2 / 3), 101-105$. 